\title{
Aberrant body markings in the Cuban banded dwarf boa, Tropidophis feicki (Squamata: Tropidophiidae)
}

\section{YUSNAVIEL GARCÍA-PADRÓN ${ }^{1,3^{*}}$, JAVIER TORRES² \& MIGUEL BOLIGAN EXPÓSITO³}

\author{
${ }^{1}$ Museo de Historia Natural 'Tranquilino Sandalio de Noda', Pinar del Río, Cuba. Martí 202, esquina Comandante Pinares, \\ Pinar del Río, CP. 20100, Cuba \\ ${ }^{2}$ Department of Ecology and Evolutionary Biology, the University of Kansas, Kansas 66044, USA \\ ${ }^{3}$ Sociedad Espeleológica de Cuba, 9na and 84, Playa, La Habana, Cuba \\ *Corresponding author e-mail: yusnaviel@gmail.com
}

$\mathrm{T}_{\mathrm{s}}^{\mathrm{h}}$ he genus Tropidophis contains 32 species distributed in South America, The Bahamas, and the Greater Antilles (Uetz \& Hošek, 2018), with a major radiation in Cuba (Hedges, 2002). Tropidophis feicki Schwartz 1957 is a small snake (411 mm snout-vent length in males, and $448 \mathrm{~mm}$ in females) endemic to forested karstic areas of western and central Cuba (Rodriguez-Cabrera et al., 2020). It is typically a nocturnal species but in caves it may be active during daytime (Schwartz \& Henderson, 1991). Here we report an observation from a cave of a specimen of $T$. feicki with aberrant body markings.

The normal body markings of $T$. feicki consist of two dorso-lateral rows of black blotches, sometimes fusing into bands across the body (Fig. $1 \mathrm{~A} \& \mathrm{~B}$ ), with a pale immaculate venter (Schwartz, 1957). This species shows colour change between night and day. During nighttime, they adopt a light coloration (light phase) (Fig. 1A) that consists of a milky white or light grey background with the blotches clearly distinguished from it. During daytime they change to a dark phase (Fig. 1B) that is characterised by a brown or dark grey background with the blotches much less contrasting with the background (Henderson \& Powell, 2009). The background colour change is mediated by an expansion or contraction of the melanophores in the skin (Hedges et al., 1989) and may be triggered by low temperatures irrespective of time of the day (Rehak, 1987).

In November 2018, during a herpetological survey of the Santo Tomás Great Cavern (STGC), Moncada, Viñales, Pinar del Río ( $22^{\circ} 54^{\prime} 44^{\prime \prime} \mathrm{N}, 83^{\circ} 84^{\prime} 68^{\prime \prime} \mathrm{W}$, WGS 84, $230 \mathrm{~m}$ a.s.I.), we captured an adult T. feicki that measured $300 \mathrm{~mm}$ SVL (Fig. 1C \& D). The snake was in the "Lechuza" gallery that is part of a daytime speleotourism trail for dozens of tourists daily. The snake was found at 21:00 h climbing a rock, 20 $\mathrm{m}$ inside the Lechuza gallery and was in the light colour phase. It had aberrant body markings where many of the black blotches were completely or partially absent, revealing areas of extended background colour (Fig. 1C \& D). We released the individual at the site of capture immediately after taking measurements and observed it for 10 minutes after release. No abnormal behaviour was detected during the observations. A photo voucher was deposited in the collection of Museo de Historia Natural "Tranquilino Sandalio de Noda" from Pinar del Río, Cuba under the label “Moncada_20181126_215617."

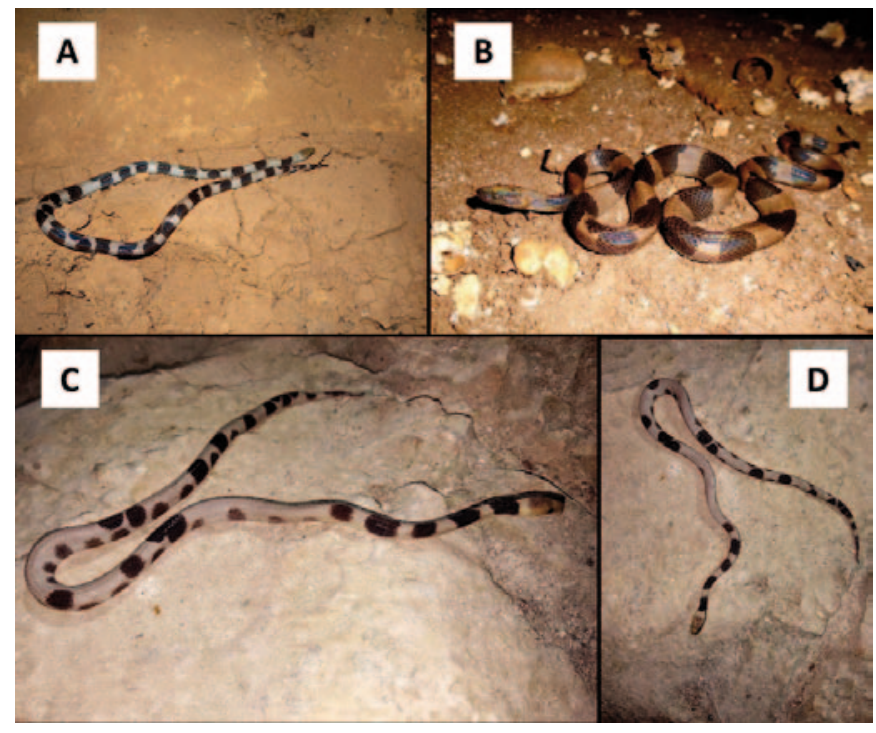

Figure 1. The body markings and coloration of T. feicki photographed in caves - A. Normal specimens in light phase, B. dark phase, and C. \& D. aberrant specimen

One possible explanation for the aberrant marking of this snake is that it is suffering from piebaldism, an abnormal body coloration in which melanocytes are absent from various parts of the body surface but not the pupil (Davis, 2007). A simple way to confirm or reject 'piebaldism' in this case would be to make observations on the snake's ability to change from the light to the dark phase. If some of the white areas on the body were not capable of darkening in the normal way then this would suggest the absence of melaocytes and confirm the aberration as piebaldism. We will endeavour to make such observations in the future.

Factors associated with piebaldism, aside from genetics, have been thought to be diet, senility, shock, disease or injury (Sage, 1962). In the current case, we would reject senility or injury because, according to its size $(300 \mathrm{~mm}$ $\mathrm{SVL}$ ), the individual was a young adult, and no sign of injury was detected. It is of interest to note that at the same locality piebaldism has recently been reported in the frog Eleutherodactylus zeus (García-Padrón \& Alonso, 2019).

Depigmentation could be a disadvantage to animals in the wild as it may render camouflage ineffective, disrupt mimicry, etc. (Uieda, 2000; Sandoval-Castillo et al., 2006). 
However, in low light conditions, such as those inside caves or during the night, such disadvantages may not apply.

We strongly suggest that there should be a longterm survey of the population of $T$. feicki in the area to determine whether the aberrant markings were provoked by environmental stresses, perhaps due to human activity, or whether the cause is hereditary. If it results from inbreeding, which might be expected in small isolated populations (Coyne \& Orr, 2004), then it would be of concern to conservationists.

\section{ACKNOWLEDGEMENTS}

This research was conducted under the project "Reproductive Ecology of the Cuban giant frog (Eleutherodactylus zeus) in Western Cuba" funded by the National Speleological Society Research Grant to LYGP. Thanks to Hilario Carmenate Rodríguez and Juan A. Castillo Pino for their assistance during the fieldwork. We are grateful for the comments and suggestions of an anonymous reviewer.

\section{REFERENCES}

Coyne, J.A. \& Orr, H.A. (2004). Speciation. Sinauer \& Associates, Sunderland, Massachusetts. 545 pp.

Davis, J.N. (2007). Color abnormalities in birds: a proposed nomenclature for birders. Birding 39: 36-46.

García-Padrón, L.Y. \& Alonso, R. (2019). Anomalous colour in a Cuban cave-dwelling frog: First record of piebaldism in the genus Eleutherodactylus (Anura: Eleutherodactylidae). Herpetological Bulletin 147: 1-3.

Hedges, S.B. (2002). Morphological variation and the definition of species in the snake genus Tropidophis (Serpentes: Tropidophiidae). Bulletin of the Natural History Museum, Zoology Series 68: 83-90.

Hedges, S.B., Hass, C. A. \& Maugel, T.K. (1989). Physiological color change in snakes. Journal of Herpetology 23: 450455.
Henderson, R.W. \& Powell, R. (2009). Natural History of West Indian Reptiles and Amphibians. University Press of Florida, Gainesville, Florida. Pp. 495.

Kazilas, C., Kalaentzis, K. \& Strachinis, I. (2018). A case of piebaldism in the Anatolian Worm Lizard, Blanus strauchi (Bedriaga, 1884), from Kastellorizo Island, Greece (Squamata: Blanidae). Herpetology Notes 11: 527-529.

Rehak, I. (1987). Color change in the snake Tropidophis feicki (Reptilia: Squamata: Tropidophiidae). Vestník Ceskoslovenské spolecnosti zoologické 51: 300-303.

Rodríguez-Cabrera, T.M., Torres J. \& Morell Savall, E. (2020). Easternmost record of the Cuban Broad-Banded snake trope, Tropidophis feicki (Squamata: Tropidophiidae). Caribbean Herpetology 71: 1-3.

Savall, E. (2020). Easternmost record of the Cuban Broadbanded Trope, Tropidophis feicki (Squamata: Tropidophiidae), of Cuba. Caribbean Herpetology 71: 1-3.

Sage, B.L. (1962). Albinism and melanism in birds. British Birds 55: 201-220.

Sandoval-Castillo, J., Mariano-Melendez, E. \& VillavicencioGarayzar, C. (2006). New records of albinism in two elasmobranchs: the tiger shark, Galeocerdo cuvier and the giant electric ray, Narcine entemedor. Cybium 30: 191-192.

Schwartz, A. (1957). A new species of boa (Genus Tropidophis) from Western Cuba. American Museum Novitates 1839: 1-8.

Schwartz, A. \& Henderson, R. (1991). Amphibians and Reptiles of the West Indies: Descriptions, Distributions, and Natural History. University of Florida Press, Gainesville. $720 \mathrm{pp}$.

Uetz, P. \& Hošek, J. (ed.) (2018). "Tropidophis feicki". Reptiles Database. Consulted in December 14, 2018. (http:// reptile-database.reptarium.cz).

Uieda, W. (2000). A review of complete albinism in bats with five new cases from Brazil. Acta Chiropterologica 2: 97105.

Accepted: 15 April 2020 